\title{
An electrochemical study on the cathode of the intermediate temperature tubular sodium-sulfur (NaS) battery
}

\author{
G. Nikiforidis ${ }^{1,2}$ *, G.J. Jongerden ${ }^{3}$, E.F. Jongerden ${ }^{3}$, M.C.M van de Sanden ${ }^{1,4}$, M.N.
} Tsampas $^{1}$

${ }^{1}$ Dutch Institute For Fundamental Energy Research (DIFFER), De Zaale 20, Eindhoven 5612AJ, The Netherlands

${ }^{2}$ Organic Bioelectronics Lab, Biological and Environmental Science and Engineering Division, King Abdullah University of Science and Technology (KAUST), Saudi Arabia

${ }^{3}$ Exergy Storage Components and Systems, Westervoortsedijk 73, 6827 AV Arnhem, The Netherlands

${ }^{4}$ Department of Applied Physics, Eindhoven University of Technology, 5600 MB Eindhoven, The Netherlands

The development of low-cost energy storage schemes is imminent in light of the ever-growing demand of electricity. Sodium-sulfur (NaS) batteries offer low-cost technology for energy storage applications due to the intrinsically high capacities of elemental sodium and sulfur as well as their abundant resources. Operating this battery technology on the intermediate range $\left(130-200^{\circ} \mathrm{C}\right)$ can lead to lower material costs, mitigate thermal management and safety issues and enhance cycle life. Herein, an electrochemical study (in the form of different carbonaceous materials) on the cathode of the IT NaS cell is performed at $150^{\circ} \mathrm{C}$ and a concentration range of 1.5 to $3 \mathrm{M}$ sodium pentasulfide dissolved in tetraglyme, showing a robust long term performance (42 days of continuous cycling) with a volumetric energy density of $83 \mathrm{Wh} \mathrm{L}^{-1}$. Most importantly, the cell was eligible for a tenfold volume scale-up considerably enhancing its capacity $(790 \mathrm{mAh})$ but in the same time somewhat hindered by mass transport, especially during the end of the discharge process as manifested by electrochemical impedance spectroscopy. 


\section{Introduction}

Recent trends in the energy storage market and technological landscape corroborate the increasingly prominent role of the former along with the rising economic maturity of renewable energy generation. Principally, solar and wind renewable sources aim to displace carbon-emitting forms of energy supply, rendering energy storage indispensable when renewable generation is not prolific. Storing energy can play a role in balancing supply with demand on the electric grid leading to emergent opportunities for gridconnected, behind the meter residential and non-residential energy storage. Therefore, large scale, low cost energy storage is paramount for reliable, resilient and efficient nextgeneration power grids. The increasing non-pumped hydro utility scale energy storage is mainly operated by battery energy storage systems (BESS). To a great extent, BESS output is based on lithium-ion ( $\mathrm{Li}$-ion) technology because of cost reduction and rapid scale-up manufacturing capacities and it is followed by sodium-based $(\mathrm{Na})$, lead-acid ( $\mathrm{Pb}$-acid) and redox flow battery (RFB) systems.

However, the significantly higher cost of raw Li compared to Na positions the last one a more attractive choice for use in BESS. ${ }^{1}$ This is due to the higher natural abundance of $\mathrm{Na}$ compared to $\mathrm{Li}$ (i.e $\mathrm{Na}$ content is $28,400 \mathrm{mg} \mathrm{kg}^{-1}$ and $1000 \mathrm{mg} \mathrm{L}^{-1}$ in the earth's crust and water, respectively). ${ }^{2}$ Coupling the $\mathrm{Na}$ metal that has a respectable electrochemical reduction potential (-2.71 V vs standard hydrogen electrode) and capacity of $1165 \mathrm{mAh} \mathrm{g}^{-1}$ with sulfur (S) that is abundant and offers an extremely high theoretical capacity of 1672 $\mathrm{mAhg}^{-1}$, leads to the NaS battery. ${ }^{3-4}$ There are three reported operating temperature regions of this system namely, high $\left(\sim 300-350^{\circ} \mathrm{C}, \mathrm{HT}\right)$, intermediate temperature $\left(\sim 130-180^{\circ} \mathrm{C}, \mathrm{IT}\right)$ and room temperature $\left(\sim 25-35^{\circ} \mathrm{C}, \mathrm{RT}\right)$. For the cases of the HT and IT, both active elements are in the liquid state $\left(\mathrm{T}_{\mathrm{m} \mathrm{Na}}=98^{\circ} \mathrm{C}, \mathrm{T}_{\mathrm{m} \mathrm{S}}=119^{\circ} \mathrm{C}\right)$ almost completely evading dendrite formation during the operation of the battery. RT batteries use metallic sodium that involves a different reaction mechanism of sulfur with sodium.

The hermetically sealed tubular HT NaS battery uses a beta-alumina solid electrolyte $\left(\beta^{\prime \prime}-\mathrm{Al}_{2} \mathrm{O}_{3}\right)$ and can deliver practical gravimetric energy densities of $\sim 130 \mathrm{Wh}$ $\mathrm{kg}^{-1}$, manifested from the 200 deployed energy storage stations worldwide. ${ }^{5}$ It exhibits advantages in terms of reasonable power and energy densities, temperature stability and high efficiency with long cycle life ( $>4500$ deep cycles), so that it exceeds the performance and scale requirements for grid-scale applications. Yet, the operating temperature of this battery is high compared to its peers such as Pd-acid, Redox flow and Li-ion and more importantly generates a series of cost and safety interconnected issues such as corrosive behavior of polysulfide melts and use of expensive materials and processing (e.g thermal compression bonded sealing). ${ }^{6}$ In addition, the high melting point of the polysulfides $\left(>280^{\circ} \mathrm{C}\right)$ hinders the stoichiometric window of $\mathrm{Na}$ to $\mathrm{S}(\sim 0.66)$, utilizing a fraction of the theoretical energy density of the system, herein being $760 \mathrm{Wh} \mathrm{kg}^{-1}$ when considering $\mathrm{Na}_{2} \mathrm{~S}_{3}$ formation ${ }^{7}$. The need to mitigate thermal management and safety issues together with driving the cost of the battery down (i.e reduced costs associated with cell packing and heat loss) laid the foundation of the IT NaS battery.

The IT NaS system has been firstly reported from Abraham et al. and NASA in the 80 's ${ }^{8-9}$. Both produced an in-depth study related to the compatibility of several nonaqueous solvents with sodium polysulfides $\left(\mathrm{Na}_{2} \mathrm{~S}_{\mathrm{x}}\right)$. Alcohol amines, amides, cyclic alcohols, and cyclic polyalcohols gave the most promising results in terms of solubility, stability and safety (i.e no hydrogen sulfide formation). A number of follow-up studies have been reported using non-aqueous or polymer electrolytes, highlighting the increasing interest on this battery system. ${ }^{10-12}$ The latest contribution on this field involves a semi- 
flow $\mathrm{NaS}$ battery operated at $150^{\circ} \mathrm{C}$ and having at the cathode a semi-solid suspension nanoscale carbon mixed with solid sulfur in a sodium iodide (NaI)/Tetraethylene glycol dimethyl ether (TEGDME) solution that can deliver a capacity of $420 \mathrm{mAh} \mathrm{g}^{-1}$ at a constant current of $0.5 \mathrm{~mA} .^{13}$

Arguably, the major challenge that arises when operating at lower temperatures entails the poor utilization of the $\mathrm{S}$ cathode and in turn the cell capacity. This issue is closely intertwined with the solubility of the $\mathrm{Na}_{2} \mathrm{~S}_{\mathrm{x}}$ in the designated non-aqueous medium. The internal resistance of the cell during charging increases on account of the precipitation of non-conductive sulfur and possibly of insoluble sodium sulfides in the vicinity of the contact surface of the BASE with the carbon matrix that typically acts as a current collector and hinders the sodium ion migration into the anode. ${ }^{14}$ Various carbon-based materials including graphite felts and carbon cloths have been investigated as effective hosts for sulfur and in turn sodium polysulfides as a result of to their high conductivity, surface modification such as heat and wet treatment, chemical stability and large surface area. ${ }^{15}$ These porous materials consist primarily of fibers. Electrons travel to the reaction sites along the carbon fibers whereas sodium polysulfides because of the high wettability on them, are readily transported across their surface as carriers. ${ }^{16}$ Another way to mitigate the ohmic resistance entails the use of carbon suspensions in the nano and macroscale, seeking to encapsulate and confine sulfur, allowing for stable operation of the system. ${ }^{13}$

Stemming from the successful realization (on an experimental stage) of another IT Na-based battery that uses similar technology to $\mathrm{NaS}$, namely IT $\mathrm{NaNiCl}_{2}{ }^{17}$, the need to more thoroughly understand and bring the IT NaS into fruition is imminent. By a priori defining the operational cell parameters including threshold temperature, solubility of polysulfide melt, current density range and (un)suitability of carbon based materials for the cathode side, the rigidity and performance of the IT NaS tubular cell is investigated here in a micro-cell as well as a scale-up configuration. The results that emerged from this study can provide a benchmark on the applicability or not of carbon-based materials as efficient hosts for high and low order polysulfides at an intermediate temperature range and in the same time pave the way for scale-up of the IT NaS battery. 


\section{Experimental}

\section{$\underline{\text { Chemicals }}$}

Sulfur (99.8\%, trace metal basis) and sodium sulfide $\left(\mathrm{Na}_{2} \mathrm{~S}_{\mathrm{x}} \cdot 9 \mathrm{H}_{2} \mathrm{O}, 98 \%\right)$ were purchased from Acros Organics ${ }^{\mathrm{TM}}$. Tetraethylene glycol dimethyl ether (TEGDME, $>99 \%$ ) was the solvent of choice and was purchased from Sigma Aldrich. The electrolyte formulation was realized in an argon-filled glovebox (Siemens, Simatic HMI). Prior to insertion in the glovebox, sulfur and sodium sulfide were vacuum dried so as to remove moisture and water as described elsewhere. ${ }^{12}$ TEGDME was purged with Argon for $2 \mathrm{~h}$ before entering the glovebox and then dried with molecular sieves ( $4 \AA$, Sigma Aldrich), accordingly. The concentration of the ionically conducting melt at the cathode (catholyte) varied between 3 and $1.5 \mathrm{M}$ sodium pentasulfide $\left(\mathrm{Na}_{2} \mathrm{~S}_{5}\right)$.

\section{$\underline{\text { Electrode materials }}$}

All carbon cloths were purchased from fuelcells etc. Their properties are listed in Table S1 and Fig. S1. The samples were washed with DI $\mathrm{H}_{2} \mathrm{O}$ (de-ionized water (Millipore) with $18 \mathrm{M} \Omega \cdot \mathrm{cm}^{-1}$ ) and iso-propyl alcohol (IPA, 98\%, Sigma Aldrich) twice, followed by overnight drying at $60^{\circ} \mathrm{C}$ in a heating oven (Carbolite, Laboratory Oven AX) and under vacuum for $5 \mathrm{~h}$. The carbon suspensions (Table S2) were washed, sonicated in IPA and dried overnight at $60^{\circ} \mathrm{C}$ and put under vacuum for $6 \mathrm{~h}$. Mesoporous carbon, graphite and glassy carbon powders were purchased from Sigma Aldrich. Cabot conductive additive was purchased by Cabot corporation and Vulcan XC 72R (carbon black) from Fuel Cell store.

\section{$\underline{\text { IT NaS Micro-cell }}$}

A tubular cell made of stainless steel (MCB Direct, SS 304, thickness: $2.5 \mathrm{~mm}$ ) with a maximum volume of $4.5 \mathrm{~mL}$ was used for micro-cell tests. The dimensions of the cell were $7 \mathrm{~cm} \times 1.5 \mathrm{~cm}$. The cell was assembled inside the glovebox where Teflon (PTFE tape, Sigma Aldrich) and a high temperature resistance glue (Mastic Silicone Kit, high temperature Bison International B.V) were used to hermetically seal the cell and create a moisture free environment.

The beta alumina $\left(\beta^{\prime \prime}-\mathrm{Al}_{2} \mathrm{O}_{3}\right)$ solid electrolyte tube (BASE) was delivered by Ionotec Ltd. Its inner structure consists of $6 \mathrm{~mm} \mathrm{OD} \times 1 \mathrm{~mm}$ wall $\mathrm{Na}^{\prime \prime}-\mathrm{Al}_{2} \mathrm{O}_{3}$ tube that is hermetically sealed by glass with a Pt-wire lead through. The latter is in touch with a carbon fiber plug, which provides electrical connection to the inner wall of the ceramic. The total length of the tube was $4.5 \mathrm{~cm}$ and that of the lead through equal to $\sim 1 \mathrm{~cm}$. The geometric surface area was equal to $3.85 \mathrm{~cm}^{2}$, assuming a cylindrical shape of the solid electrolyte. The received BASE electrodes were primed with $100 \mathrm{mg}$ of $\mathrm{Na}$, so preceding experimentation, a prolonged charge was initiated to fill the tube with sodium and moderate its resistance. Cleaning of the BASE was done through washing in hot demineralized water

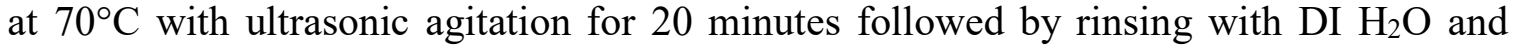
drying in the oven for $1 \mathrm{~h}$.

In the case of carbon cloth, a $3.5 \mathrm{~cm} \times 4 \mathrm{~cm}$ piece was cut and wrapped with tungsten wire (1 mm, 99.95\%, Alfa Aesar) around the BASE as previously reported in the literature. ${ }^{18}$ By using the Image $\mathrm{J}$ software (National Institute of Health and $\mathrm{LOCl}$, University of Wisconsin), the surface area was calculated equal to $5.3 \mathrm{~cm}^{2}$. The amount of carbonaceous powders introduced to the cell was $1 \mathrm{vol} \%$, in line with previous reported studies. ${ }^{13}$ A stirrer bar (BRAND ${ }^{\circledR}$ PTFE crosshead, Sigma Aldrich) was employed in all cells with the rpm (revolutions per minute) set at 600 . 
After assembling the cell, it was taken off the glovebox and placed inside a beaker filled with heated silicon oil (Sigma Aldrich, boiling point: $200^{\circ} \mathrm{C}$ ) on a hot plate (Velp Scientifica AM4). The desired temperature conditions were monitored by a thermocouple type $\mathrm{k}$. Taking into account the thickness of stainless steel $(2.5 \mathrm{~mm})$, the temperature of the silicon oil was set $10^{\circ}$ higher than the desired cell operating temperature so as to achieve uniform and precise temperature distribution inside the cell.

\section{$\underline{\text { IT NaS scale-up cell }}$}

The dimensions of the scale-up cell able to accommodate $40 \mathrm{~mL}$, were $11 \mathrm{~cm} \times 3$ $\mathrm{cm}$. The BASE of the scale-up cell was designed and delivered by Exergy Ltd. The outer and internal diameters were 8.5 and $6.5 \mathrm{~mm}$, respectively while the length of the tube was $55 \mathrm{~mm}$. The wall thickness of the membrane was $\sim 0.75 \mathrm{~mm}$. Here, the outer surface of the BASE $\left(13.6 \mathrm{~cm}^{2}\right)$ was covered with a perforated platinum current collector, having about $50 \%$ coverage of the beta-alumina. The Pt grid provides electrical path through the entire anode side. The received BASE electrodes were primed with sodium in a similar manner to that of the micro-cell.

Electrochemical tests and material characterization

Galvanostatic (i.e constant current charge/discharge cycles (CCD)) and cyclic voltammetry tests were carried out with an IVIUMnSTAT potentiostat (Ivium technologies). For the CCD tests, the operational potential window was set between 2.6 and $1.8 \mathrm{~V}$, for charge and discharge, respectively. The Tafel and polarization resistance measurements of the cell were conducted at a scan rate of $1 \mathrm{mVs}^{-1}$ and at $\pm 200 \mathrm{mV}$ and $\pm 10 \mathrm{mV}$ from the open circuit potential, respectively. Electrochemical impedance spectroscopy (EIS) was conducted with the same potentiostat at a frequency range between $1 \mathrm{mHz}$ and $0.2 \mathrm{MHz}$ and an amplitude of $10 \mathrm{mV}$. For the three-electrode voltammetry, a Pt wire was used as a counter electrode (Alfa Aesar, $0.5 \mathrm{~mm}$ annealed) and carbon rods (Sigma Aldrich, 99.5\% graphite) for working and reference electrodes, respectively.

A $532 \mathrm{~nm}$ laser (AvaRaman-532 TEC, Avantes) was used to analyze the electrolyte samples on a sealed quartz cuvette after the cell was disassembled in the Argon glovebox. Prior to testing, the cuvette was inserted in a heating oven to reach the desired temperature. The Raman spectroscopy measurements on the carbon cloths were executed in air before and after cycling. X-ray diffraction (Brucker D8 Advance Eco) measurements on the surface of the carbon materials and the solid electrolyte were conducted through a $\mathrm{Cu}$ $\mathrm{K}_{\alpha}$ tube. The surface morphology of the current collectors was investigated by scanning electron microscopy (FEI Quanta 3d FEG instrument), at an acceleration voltage of $15 \mathrm{keV}$ and working distance of $7 \mathrm{~mm}$.

\section{Results and Discussion}

\section{Operation of IT NaS cell}

The IT range of operation of this battery system is determined from the $\mathrm{Na} / \mathrm{Na}_{2} \mathrm{~S}_{\mathrm{x}}$ phase diagram of Gupta and Tischer ${ }^{19-20}$ as depicted in Fig. 1a. It was introduced in parallel with the development of the $\mathrm{HT} \mathrm{NaS}$ system $\left(300-350^{\circ} \mathrm{C}\right)$ and can suitably categorize the IT and RT regions too. It is evident that by operating the cell in the IT range, a greater portion of sulfur can be accessed that can lead to amplified energy and power densities. The IT NaS planar battery confined in a metal case, consists of molten sodium contained within a beta alumina, which acts as a membrane and is surrounded by molten sulfur and polysulfide intermediates dissolved in the electrolyte of choice, herein called catholyte (Fig. 
1a). By operating the cell above the melting temperature of $\mathrm{Na}$, a conductivity of the order of $10^{5}(\Omega \cdot \mathrm{cm})^{-1}$ is achieved but most importantly the formation of metallic dendrites at the negative electrode in the course of charging is evaded. The sodium-sulfur reaction is exothermic for the discharge process and endothermic during charge. In the course of the discharge process, electrons flow in the external circuit of the battery while sodium ions $\left(\mathrm{Na}^{+}\right)$travel through the BASE to the cathode and react with sulfur to produce sodium polysulfide intermediates (i.e $\mathrm{Na}_{2} \mathrm{~S}_{\mathrm{x}}, 3<x<5$ ). Through the reversible charge process, the $\mathrm{Na}_{2} \mathrm{~S}_{\mathrm{x}}$ release the $\mathrm{Na}^{+}$through the electrolyte to recombine as elemental sodium at the anode. Meanwhile, the electrons flow out of the external circuit of the battery as demonstrated in Fig. 1c. The reactions governing the cell are presented below:

$\begin{array}{ll}\text { Anode } & 2 \mathrm{Na}=2 \mathrm{Na}^{+}+2 \mathrm{e}^{-} \\ \text {Cathode } & x \mathrm{~S}+2 \mathrm{e}^{-}=\mathrm{S}_{x}{ }^{2-} \\ \text { Overall } & 2 \mathrm{Na}+x \mathrm{~S}=\mathrm{Na}_{2} \mathrm{~S}_{x}\end{array}$

The operational window of this battery system obeys the phase diagram of Fig. 1a and lies between 1.78 and $2.08 \mathrm{~V}$. At $1.78 \mathrm{~V}$, the formation of lower order polysulfides, typically $\mathrm{Na}_{2} \mathrm{~S}_{3}$, signify the discharge of the cell. In theory, a complete discharge involves the subsequent formation of $\mathrm{Na}_{2} \mathrm{~S}_{2}$ and $\mathrm{Na}_{2} \mathrm{~S}$. Nevertheless, these polysulfides are solid, not rechargeable and electronically non-conductive. ${ }^{21}$ The cut-off potential during charge exceeds $2.08 \mathrm{~V}$ (i.e the $\mathrm{Na}_{2} \mathrm{~S}_{5}$ phase region) and reaches nominally $2.6 \mathrm{~V}$.

\section{Cathode current collector - carbon cloth}

It is well established that the ionic conductivity of the BASE and the solubility of the $\mathrm{Na}_{2} \mathrm{~S}_{x}$ are temperature dependent. ${ }^{22}$ In order to identify the low end temperature of this system, a polarization study was conducted between 130 and $190^{\circ} \mathrm{C}$, covering the whole intermediate temperature range. Limited charge-discharge cycles of $1 \mathrm{~h}$ duration at different current densities ranging from 5 to $20 \mathrm{~mA} \mathrm{~cm}^{-2}$ were performed consecutively with a carbon cloth serving as a current collector in a solution consisting of TEGDME and $2 \mathrm{M}$ sodium pentasulfide $\left(\mathrm{Na}_{2} \mathrm{~S}_{5}\right)$ (Fig. S2). In accordance with previous studies, the carbon cloth was placed in-between the BASE and the metal cell container. ${ }^{16,20}$ The choice of solvent was made driven by previous literature ${ }^{8,11-13}$ as it has a respectable solubility for the active materials (i.e $>2 \mathrm{M} \mathrm{Na}_{2} \mathrm{~S}_{x}, x \geq 7$ ) ascribed to loose long-chain $\mathrm{S}$ polymer structures in TEGDME.

As expected from Fig. 2a, the voltaic efficiency $\left(\eta_{V}\right)$ calculated as the average discharge potential over the one all through charge, was temperature dependent. Elevated temperatures yield higher $\eta_{V}$ values throughout the inspected current density range, viz. $\pm 1-20 \mathrm{~mA} \mathrm{~cm}^{-2}$. Yet, the difference between 150 and $190^{\circ} \mathrm{C}$ is $\sim 3-5 \%$ among $\pm 5-15 \mathrm{~mA}$ $\mathrm{cm}^{-2}$, not as significant as when compared with $130^{\circ} \mathrm{C}(\sim 15 \%$ for the same current density range), suggesting that a lower limit of $150^{\circ} \mathrm{C}$ is plausible under this salt-free polysulfide catholyte and tubular configuration. The $\eta_{V}$ values at $150{ }^{\circ} \mathrm{C}$ were equal to $95 \%$ at $\pm 1 \mathrm{~mA}$ $\mathrm{cm}^{-2}$ and dropped to $70 \%$ at $\pm 20 \mathrm{~mA} \mathrm{~cm}$ showing a $20 \%$ decrease, in tandem with a twentyfold increase in the applied current density.

In light of the above, carbon cloths with different physical characteristics, outlined in Table S1, were investigated in a battery configuration under the previously established catholyte and temperature conditions (i.e $2 \mathrm{M} \mathrm{Na}_{2} \mathrm{~S}_{5}$ and TEGDME, $150^{\circ} \mathrm{C}$ ). Coupled with their low-density $\left(<1.5 \mathrm{~g} \mathrm{~cm}^{-3}\right)$, the current collectors have different degrees of porosity reaching $90 \%$ in the case of the control sample. High porosity is a requisite for efficient electron and ion transport for battery applications. In addition, two of the samples contained a one-sided microporous layer (MPL). The presence of the latter is expected to mediate 
better the $\mathrm{Na}_{2} \mathrm{~S}_{\mathrm{x}}$ and contribute to lower ohmic resistances by pushing $\mathrm{S}$ away from the BASE, the same manner graphite felt electrodes see to, for the case of the HT cells. ${ }^{16}$ The MPL layer was more advantageous when facing the electrolyte (Fig. S3a) and therefore was used in that mode. What is more, the different thicknesses of the samples containing carbon fiber cloth and woven carbon fiber, did not seem to greatly influence the cell ohmic resistance when measured at the open circuit potential, viz. $2.07 \mathrm{~V}$, lingering between 3 and $4 \Omega$ (Fig. S3b). Yet, upon cell operation, an optimal thickness should be apparent as manifested for the same material in other energy storage applications. ${ }^{23}$

The cells were cycled galvanostatically for $6 \mathrm{~h}$ at different current densities ranging from \pm 0.5 and $7.5 \mathrm{~mA} \mathrm{~cm}^{-2}$, corresponding to capacities between 12 and $180 \mathrm{mAh}$. Overall, 50 cycles were performed for each sample. Interestingly, the results from this study advocate against the introduction of carbon cloths as current collectors at $150^{\circ} \mathrm{C}$. Neither the MPL nor the different thickness and porosity of the carbon cloths seem to ameliorate the overall cell performance as seen from Fig. $2 \mathrm{~b}$. The current collect containing carbon fibers and a MPL, exhibited $\sim 2 \%$ greater efficiencies at \pm 5 and $7.5 \mathrm{~mA} \mathrm{~cm}^{-2}$ while at higher current densities the difference marginally shifted to 5\%. What's more, the most convincing proof regarding the non-compatibility of the carbon cloths under these conditions came from their ex-situ analysis.

SEM pictures of the carbon cloth (MPL) sample revealed the formation of clusters on top and in-between the carbon cloth fibers (Fig. S4). The size of the clusters is not uniform ranging from 1 to $100 \mu \mathrm{m}$, suggesting a local effect on the pores of the cloths dependent on the nucleation energy of the polysulfides. Low order polysulfides have low nucleation energy and are more likely to precipitate in the nanopores of the carbon cloth (Figs S4c and S4d) whilst larger solid products as the ones shown in Figs S4e and S4f precipitate on the surface due to their insoluble nature. ${ }^{24}$ Similar SEM findings were evident in all the samples of Table S1. XRD analyses confirmed the presence of higher order polysulfides (i.e $\mathrm{Na}_{2} \mathrm{~S}_{5}$ and $\mathrm{Na}_{2} \mathrm{~S}_{4}$ ) and $\mathrm{S}$, all in crystalline form, on the top and inbetween the carbon fibers (Fig. S5a). ${ }^{1,}{ }^{25}$ Sulfur, was also detected by Raman spectroscopy as clearly demonstrated in Fig. S5b. ${ }^{26}$ The high number of clusters and more significantly the presence of $\mathrm{S}$ that is electronically insulating around the accessible surface area will impede the long-term reversible operation of the cell. The permeability of the active polysulfide species and sodium ions during the operation of the battery becomes mass transport limited, leading to capacity losses.

Regarding the rigidity of the carbon cloths, while SEM and optical inspection indicated no perforation or breaking, Raman spectroscopy revealed that their structural integrity and bonding structure were severely compromised. Characteristic Raman bands of carbon structures were found at 1330 (D band) and $1590 \mathrm{~cm}^{-1}$ ( $\mathrm{G}$ band). The $\mathrm{I}_{\mathrm{D}} / \mathrm{I}_{\mathrm{G}}$ ratio of all the cycled samples shifted negatively to a great extent. As an example, Fig. S5c shows the Raman spectra of the carbon cloth (MPL) sample where the $\mathrm{I}_{\mathrm{D}} / \mathrm{I}_{\mathrm{G}}$ ratio decreased from 1.72 to 1.16 that it was originally, indicating a substantial level of defect on its structure. This shift is attributed to the enlargement of the D band of the carbon cloth that describes the disordered structure of graphene. ${ }^{27-28}$

\section{Carbon suspensions for the catholyte}

Another documented way to improve polysulfide solubility and inhibit nondesirable formation of discharge products entails the practice of additives. The latter seek to stabilize the long chain polysulfides throughout discharge, improve S solubility and enhance electronic transfer between active $\mathrm{S} / \mathrm{S}^{2-}$ species. Documented cases of additives on the $\mathrm{NaS}$ battery include selenium $(\mathrm{Se})$, metal sulfides, tetracyonoethylene $\left(\mathrm{C}_{6} \mathrm{~N}_{4}\right)$ and 
carbon suspensions. ${ }^{15}$ Regarding the latter, the development of a $\mathrm{RT} \mathrm{Na}_{2} \mathrm{~S}_{6}$ polysulfide catholyte with a composite matrix of activated carbon dispersed into carbon nanofiber has been reported ${ }^{29}$ while a more recent demonstration of an IT semi-flow NaS battery utilized at the cathode Ketjenblack (KB), a semi-solid suspension nanoscale carbon ( $1 \mathrm{vol} \%$ ) mixed with $\mathrm{S}, \mathrm{NaI}$ and TEGDME. ${ }^{13}$ The significance of these studies lies on the implementation of a conductive suspension with a particle size small enough to stabilize the reactants and formed products, thereby initiating fast electron transfer and also to reduce the leakage current during the operation of the cell.

To this end and consistent with the amount used from the reported study ${ }^{13}$, carbon suspensions with different particle sizes, ranging from 0.01 to $20 \mu \mathrm{m}$ (Table S2) were examined in a kinetic study to determine whether they can mitigate the overall cell resistance. Electrochemical impedance spectroscopy $\left(R_{1}\right.$ and $\left.R_{2}\right)$ and polarization resistance $\left(R_{p}\right)$ measurements were performed on a wetted BASE at $150^{\circ} \mathrm{C}$ and $2.07 \mathrm{~V}$, the latter being the cell open circuit potential in the presence of $2 \mathrm{M} \mathrm{Na}_{2} \mathrm{~S}_{5}$. The values are presented in a non-normalized manner and accurately compare the results from the two different electrochemical methods. $R_{p}$ stems from the linear fitting of the polarization resistance plot, $\pm 10 \mathrm{mV}$ of the cell open circuit potential whilst $R_{1}$ and $R_{2}$ describe the ohmic and interfacial resistances of the cell, derived from the equivalent circuit fitting of the Nyquist plot. An example of both techniques is displayed in Fig. S6 for a cell containing $2 \mathrm{M} \mathrm{Na}_{2} \mathrm{~S}_{5}$ in TEGDME and $1 \mathrm{vol} \%$ Vulcan XC 72R.

Fig. 3 summarizes the results of this study where irrespective of particle size, the carbon suspensions did not improve the cell resistance. On the contrary, the cell polarization resistance was higher in all cases when compared with plain carbon cloth and control (i.e no additives or carbon cloth present). More precisely, the ohmic part of the cell describing the electrically conductive components of the cell such as BASE, carbon fibers, catholyte and leads was similar for all cells, lingering between 6.5-10 $\Omega$. The sodium/electrolyte interfacial resistance however, was considerably greater when compared to the control measurement by a factor of 2 to 4 , reaching $25 \Omega$ for the case of Cabot carbon suspension. Presumably, the suspensions block the transport of the electrons and ions, impeding mass transport. On top of the above, sedimentation was evident upon disassembly of the cells further supporting the non-compatibility of the suspensions with the polysulfides at these operating conditions.

\section{IT NaS micro-cell}

Quite interestingly from Fig. 3, in the absence of carbon related materials, there is a low interfacial cell resistance, stretching between 2 and $3 \Omega$. This simpler carbon-free configuration allows the molecules to freely move between the BASE and the stainless steel casing, the latter here acting as the cathode and current collector in the same time. Positioning the BASE close enough to the stainless steel is paramount for avoiding mass transport limitations, largely created from the formation of polysulfides in the course of the operation of the battery. Taking into account the thickness of the metal case and the height of the stirrer bar, the spacing between BASE and stainless steel was minimized to $2 \mathrm{~mm}$, with the intention of diminishing the ohmic solution resistance. The performance of this simplified battery at $150^{\circ} \mathrm{C}$ was further investigated as a function of electrolyte concentration.

The initiative of increasing the concentration emerged from a parallel study, focusing on the solubility of $\mathrm{Na}_{2} \mathrm{~S}_{5}$ at $150^{\circ} \mathrm{C}$ as a function of the cell capacity, portrayed in Fig. 4. The concentration of $\mathrm{Na}_{2} \mathrm{~S}_{5}$ reached $3 \mathrm{M}$, being quite viscous but still soluble when continuously stirred at $150^{\circ} \mathrm{C}$. The above concentration corresponds to $6 \mathrm{M}$ of sodium and 
$15 \mathrm{M}$ of sulfur dissolved in TEGDME. We anticipate that a fraction of $\mathrm{Na}^{+}$is not solvated by TEGDME and is free to interact directly with the electrochemical reactants and products, given that there is no supporting salt herein. The capacity of the cell holding $3 \mathrm{M} \mathrm{Na}_{2} \mathrm{~S}_{5}$ climbed to $230 \mathrm{mAh}$ at a current density of $2.5 \mathrm{~mA} \mathrm{~cm}^{-2}$, almost double of that at $1.5 \mathrm{M}$ $\mathrm{Na}_{2} \mathrm{~S}_{5}$ that attained $125 \mathrm{mAh}$, as illustrated in Fig. 4. Still, the choice of $2.5 \mathrm{M} \mathrm{Na}_{2} \mathrm{~S}_{5}$ holding a capacity of $185 \mathrm{mAh}$ was preferred, due to mass transfer limitations depicted here by the electrolyte resistance $\left(R_{s}\right)$ and also in Fig. S7 where a CCD cycleability study at $3 \mathrm{M} \mathrm{Na}_{2} \mathrm{~S}_{5}$ revealed low capacity retention. The $R_{s}$ values at $150^{\circ} \mathrm{C}$ were determined experimentally from three-electrode impedance spectroscopy experiments. $R_{S}$ gradually increased with higher $\mathrm{Na}_{2} \mathrm{~S}_{5}$ concentrations to $2 \Omega$ at $3 \mathrm{M} \mathrm{Na}_{2} \mathrm{~S}_{5}$, a twofold jump from 1.5 $\mathrm{M} \mathrm{Na}_{2} \mathrm{~S}_{5}$. Not surprisingly, in all cases, $R_{S}$ dropped with the increase of temperature owing to the higher ionic mobility of the $\mathrm{Na}_{2} \mathrm{~S}_{\mathrm{x}}, \mathrm{Na}$ and $\mathrm{S}$ ions.

The battery containing $2.5 \mathrm{M} \mathrm{Na}_{2} \mathrm{~S}_{5}$ in TEGDME was stable for 36 deep cycles (42 days of continuous cycling) at $150^{\circ} \mathrm{C}$ (Figs S8a and S8b) with a capacity retention of $97.5 \%$ as evidenced from Fig. 5. The coulombic efficiency $\left(\eta_{C}\right)$ lingered above $98.8 \%$ and the average voltaic efficiency was $c a$. $86 \%$ for a current density of $2.5 \mathrm{~mA} \mathrm{~cm}^{-2}(10 \mathrm{~mA})$ (Fig. $\mathrm{S} 8 \mathrm{c})$. Assuming a nominal voltage of $2.07 \mathrm{~V}$, that is the cell electromotive force at the two phase region where the melt is completely ionized containing solely $\mathrm{Na}$ and $\mathrm{Na}_{2} \mathrm{~S}_{\mathrm{x}}$ ions ${ }^{16}$, the volumetric energy density for this battery corresponds to $83 \mathrm{Wh} \mathrm{L}^{-1}$, on par with other reported all-liquid battery systems. ${ }^{30}$ The performance of this cell in terms of current density and volumetric energy density outperforms any of the previously published studies on this technology and temperature. ${ }^{12-13}$

The XRD results from the BASE before and after cycling (Fig. S9a) did not exhibit any new peaks suggesting no structural change in the grain boundary of the ceramic material ${ }^{31-32}$, having an amorphous morphology comprised of beta alumina grains with a particle size less than $5 \mu \mathrm{m}$. Ex-situ Raman spectroscopy of the cycled electrolyte confirmed the presence of $\alpha-\mathrm{Na}_{2} \mathrm{~S}_{5}$ and $\mathrm{Na}_{2} \mathrm{~S}_{4}$ (Fig. S9b), in accordance with other reported studies on the same medium. ${ }^{12,33}$ Moreover, the volume of the catholyte at the time of disassembly was $\sim 8 \%$ less than when assembled, attributed to solvent evaporation and less likely to sulfur vapour formation. The kinetic study conducted before and after long-term cycling revealed two important findings. First, $E_{o c v}$ shifted $50 \mathrm{mV}$ more positive in favour of the $\mathrm{S}$ rich phase and the ionically conducting $\mathrm{Na}_{2} \mathrm{~S}_{5}$ melt (Fig. S10a). Therefore, the capacity losses are ascribed to the formation of $\mathrm{S}$ since it is well known that $\left(\beta-\mathrm{S}_{8}\right)$ solidifies at $115^{\circ} \mathrm{C} .{ }^{34}$ Second and far more intriguing, the polarization resistance of the cell after cycling was somewhat improved shifting from 12.3 to $8 \Omega$ (Figs S10b and S10c). We attribute this improvement to the better wetting of the BASE with prolonged cycling. A separate example of the wetting effect (i.e filling of BASE with sodium) is outlined in Fig. S11 where the cell resistances $\left(R_{1}\right.$ and $\left.R_{2}\right)$ markedly decrease from 22 to $6 \Omega$ after prolonged charging, equivalent to a filling of $0.8 \mathrm{~g}$ of $\mathrm{Na}$.

\section{IT NaS scale-up cell}

After successfully demonstrating the stability of the stainless steel/BASE cell, labelled as micro-cell, a scale-up was initiated in an attempt to investigate the system's performance consistency. The $E_{o c v}$ was similar to the one of the micro-cell, $c a .2 .075 \mathrm{~V}$ and in line with the sulfur rich state of the $\mathrm{Na} / \mathrm{NaS}_{\mathrm{x}}$ phase diagram (Fig. 1a.) From Fig. 5, it can be clearly seen that the tenfold increase in the volume of the cell $(40 \mathrm{~mL})$ led to a cell capacity of $790 \mathrm{mAh}$ for the same applied current density $\left(2.5 \mathrm{~mA} \mathrm{~cm}^{-2}\right)$. The capacity retention for 5 deep cycles was $95 \%$ in line with the results of the micro-cell, yet the number of cycles here is significantly smaller (Fig. S12). The smaller number of cycles achieved 
here is ascribed to... The $\eta_{v}$ lingers at $84 \%$ for the first cycle but drops to $80 \%$ at the fifth $\eta_{C}$ is $c a .99 \%$. The tenfold volume increase did not linearly correlate with the capacity and volumetric density (herein equal to $c a .45 \mathrm{Wh} \mathrm{L}^{-1}$ ), suggesting that mass transport inhibits the system amidst scale-up.

Therefore, a follow-up electrochemical impedance study at different states of charge and discharge, labeled as (i) $\rightarrow$ (iv) in Fig. 6a was conducted. The Nyquist plots taken at points (i) and (iii) are midway of the charge and discharge processes, respectively. They are modelled by a resistance $R_{l}$ that refers to the electrically conductive components of the cell including BASE, catholyte, molten $\mathrm{Na}$, stainless steel casing and leads, in parallel with a second resistance $R_{2}$ that represents the $\mathrm{Na}$ /electrolyte interface and a constant phase element $(C P E)$ that models the inhomogeneity of this interface. The evidently taller and larger semi-circle of (iii) compared to (i) advocates towards a more significant charge transfer resistance throughout discharge (viz. $R_{2 \text { (i) }}=5.99 \Omega$ as opposed to $R_{2}$ (iii) $=8.01 \Omega$ ), rendering this process the limiting one for the IT NaS cell.

Notable differences are also found at points (ii) and (iv) that correlate to the final stages of charge and discharge, respectively. At the end of the charging process (point (ii)), the considerably enlarged semi-circle versus point (i) (Fig. 6b) directs towards a hefty interfacial resistance $(12.5 \Omega)$ as a result of the hindered charge transfer or ionic diffusion, which in turn impedes the current flow. This results in a slightly depressed initial reduction cell potential equal to $\sim 1.9 \mathrm{~V}, 180 \mathrm{mV}$ away from $E_{o c v}$. Charge transfer is ameliorated with prolonged discharge as the potential reaches $2.0 \mathrm{~V}$ followed by a rapid fall in the voltage. At point (iv), the emergence of a new semi-circle at the high frequency region $(20 \mathrm{kHz})$ complemented with additional $R$ and $C P E$ elements, is ascribed to the de-wetting of the BASE. ${ }^{35}$ At the initial stage of discharge (i.e $2 \mathrm{Na}+5 \mathrm{~S} \rightarrow \mathrm{Na}_{2} \mathrm{~S}_{5}$ ) molten sodium makes intimate contact with the solid electrolyte while the Na content proliferates upon complete filling of the cathode with $\mathrm{Na}_{2} \mathrm{~S}_{5}$. After some time, the active area of the BASE becomes smaller suggesting that the current on the active part of the membrane increases and locally a higher concentration of lower sodium polysulfides is formed, leading to a decrease in the cell potential and a surge in the cell resistance, manifested here at the LF region, reaching $15.6 \Omega$ (Fig. 6c). We presume that the resistance here arises by a combination of the interfacial phenomena between the catholyte and BASE along with the somewhat compromised ionic conductivity of BASE itself (i.e grain boundary resistance, $50 \mathrm{mS} \mathrm{cm}$ ${ }^{1}$ at $\left.150{ }^{\circ} \mathrm{C}\right) .{ }^{15,22}$ As a result, operating the cell at a $90 \%$ depth of discharge (DOD) is advised, in order to prevent a steep increase in the cell's internal resistance.

Apart from the BASE and charge transfer limitations, the ohmic segment of the cell also contributes to the overall cell resistance. Assuming a negligible contact resistance at the $\mathrm{Na} \mid \beta^{\prime \prime}-\mathrm{Al}_{2} \mathrm{O}_{3}$ interface due to the high electrical conductivity of molten $\mathrm{Na}(\mathrm{ca} .2 .1 \times$ $\left.10^{7} \mathrm{~S} \mathrm{~m}^{-1}\right)^{15}$, the ohmic part is mainly represented by the catholyte resistance. At the time of lengthy charging, it increased by a factor of 1.6 (e.g from 2.2 to $3.6 \Omega$ ) while through discharge a similar trend is noticed (factor of $\sim 1.45$ from Fig. $6 \mathrm{c}$ ). The changes in the catholyte's chemical composition throughout deep cycling leads to the formation of high and low order polysulfides $\left(\mathrm{Na}_{2} \mathrm{~S}_{x}, x>5\right.$ and $\left.x<3\right)$ that can impede the electronic and ionic conductivity of the solution in TEGDME, as reported previously. ${ }^{36}$ Finally, points (ii) and (iv) from Figs $6 \mathrm{~b}$ and Fig.6c connote that the cell throughout its operation exhibits an asymmetry effect, that is the internal cell resistance for the duration of discharge is higher than during charge. This effect can be also manifested by the initial part of the charging process where the potential sits at $\sim 2.2 \mathrm{~V}, 115 \mathrm{mV}$ from $E_{o c v}$ while for discharge it is 180 $\mathrm{mV}$. 


\section{Conclusions}

To conclude, a tubular IT NaS cell without the presence of supporting salt was discussed here showing good stability and reversibility at $150^{\circ} \mathrm{C}$, significantly lower than the temperature of the HT NaS system. After discarding the use of microporous layers, fibers and suspensions as current collectors and additives, the carbon-free cell using stainless steel as a collector and electrode, was able to robustly perform long term cycling (42 days) under $2.5 \mathrm{~mA} \mathrm{~cm}^{-2}$, generating a volumetric energy density of $83 \mathrm{Wh} \mathrm{L}^{-1}$. The deployed current density based on the geometric area of the BASE is according to our knowledge the highest recorded for this system and temperature. The capacity retention of the cell was $97 \%$ after 36 deep cycles while post-mortem analysis on the cell components did not show any signs of degradation. The high solubility of $\mathrm{Na}_{2} \mathrm{~S}_{5}$ with TEGDME ( $3 \mathrm{M}$ at $150^{\circ} \mathrm{C}$ ) is comparable and in several cases higher than other aqueous and non-aqueous battery systems. ${ }^{30}$ Deploying such high concentrations can lead to high energy density, which in turn signify more electricity per kilogram of battery mass across its lifetime.

Going a step further, a scale-up of this battery system was introduced, yielding an almost fourfold increase in the capacity under the same current density, reaching $\sim 800$ $\mathrm{mAh}$. The electrochemical impedance study on the different stages of cell operation elucidated that the cut-off capacity limit for discharge should not exceed $90 \%$ given that the de-wetting of the solid electrolyte together with interfacial charge transfer and ohmic limitations can lead to grave cell resistances $(15.6 \Omega)$ that hinder the operation of the cell.

The subsequent challenges for the IT NaS battery call for the i) introduction of higher current densities and ii) mitigation of mass transfer limitation on larger cell volumes. The applied current densities herein are on the low end of Na-based batteries, largely ascribed to the compromised ionic conductivity of the BASE at this temperature range. ${ }^{22}$ Several strategies have been deployed for Na-based batteries (Na-ion, Zebra, NaS), in quest of alleviating the ionic conductivity, such as introduction of polymers and wetting layers as well as reduction of the BASE layer thickness. ${ }^{15,37}$ Aside from the ionic conductivity, securing a good anode wetting by applying stringent DOD limits and introduction of flow are the key points to reach higher current densities. Regarding the latter, previous studies on static and flow cell batteries have shown a great improvement by virtue of better mixing of the electrolyte (in this case the $\mathrm{Na}_{2} \mathrm{~S}_{5}$ melt) leading to superior mass transfer and volumetric energy density and also mitigated cell resistance. ${ }^{38}$ The manifestation of a tubular IT NaS flow cell is currently under way.

\section{Acknowledgments}

The authors would like to thank J.J.A Zeebregts (TU.e) for her assistance on the drying of the chemicals, I. Schreuer-Piet (TU.e) for her assistance in SEM measurements and to B. Lamers (DIFFER) for his assistance in the drawing of the cell and I. Dogan (TNO) for

the useful discussions. Finally, the authors acknowledge Ionotec Ltd. for cooperation and the delivery of dedicated beta-alumina membranes. 


\section{References}

1. B. Swain, Separation and Purification Technology, 172, 388 (2017).

2. Y. Liu, X. Liu, T. Wang, L.-Z. Fan and L. Jiao, Sustainable Energy \& Fuels, 1, 986 (2017).

3. C. Wadia, P. Albertus and V. Srinivasan, Journal of Power Sources, 196, 1593 (2011).

4. B. Zhang, R. Dugas, G. Rousse, P. Rozier, A. M. Abakumov and J.-M. Tarascon, Nature Communications, 7, 10308 (2016).

5. P. Adelhelm, P. Hartmann, C. L. Bender, M. Busche, C. Eufinger and J. Janek, Beilstein Journal of Nanotechnology, 6, 1016 (2015).

6. T. Oshima, M. Kajita and A. Okuno, International Journal of Applied Ceramic Technology, 1, 269 (2004).

7. M. Hiremath, K. Derendorf and T. Vogt, Environmental Science \& Technology, 49, 4825 (2015).

8. K. Abraham, R. Rauh and S. Brummer, Electrochimica Acta, 23, 501 (1978).

9. W. L. Fielder and J. Singer, NASA STI/Recon Technical Report N, (1978).

10. R. M. Darling, K. G. Gallagher, J. A. Kowalski, S. Ha and F. R. Brushett, Energy \& Environmental Science, 7, 3459 (2014).

11. C.-W. Park, H.-S. Ryu, K.-W. Kim, J.-H. Ahn, J.-Y. Lee and H.-J. Ahn, Journal of Power Sources, 165, 450 (2007).

12. X. Lu, B. W. Kirby, W. Xu, G. Li, J. Y. Kim, J. P. Lemmon, V. L. Sprenkle and Z. Yang, Energy \& Environmental Science, 6, 299 (2013).

13. F. Yang, S. M. A. Mousavie, T. K. Oh, T. Yang, Y. Lu, C. Farley, R. J. Bodnar, L. Niu, R. Qiao and Z. Li, Advanced Energy Materials, 8, 1701991 (2018).

14. S. I. Kim, W. I. Park, K. Jung and C.-S. Kim, Journal of Power Sources, 320, 37 (2016).

15. K. B. Hueso, V. Palomares, M. Armand and T. Rojo, Nano Research, 10, 4082 (2017).

16. J. Sudworth, Journal of Power Sources, 11, 143 (1984).

17. G. Li, X. Lu, J. Y. Kim, K. D. Meinhardt, H. J. Chang, N. L. Canfield and V. L. Sprenkle, Nature Communications, 7, 10683 (2016).

18. J. Zhang, H. Huang, J. Bae, S.-H. Chung, W. Zhang, A. Manthiram and G. Yu, Small Methods, 2, 1700279 (2018).

19. N. K. Gupta and R. P. Tischer, Journal of The Electrochemical Society, 119, 1033 (1972).

20. G. Janz, R. Murphy and W. Spiak, Journal of Applied Electrochemistry, 10, 789 (1980).

21. R. Steudel and Y. Steudel, Chemistry-A European Journal, 19, 3162 (2013).

22. Z. Yang, J. Zhang, M. C. Kintner-Meyer, X. Lu, D. Choi, J. P. Lemmon and J. Liu, Chemical Reviews, 111, 3577 (2011).

23. H.-K. Lee, J.-H. Park, D.-Y. Kim and T.-H. Lee, Journal of Power Sources, 131, 200 (2004).

24. I. Kim, J.-Y. Park, C. H. Kim, J.-W. Park, J.-P. Ahn, J.-H. Ahn, K.-W. Kim and H.J. Ahn, Journal of Power Sources, 301, 332 (2016).

25. H. Ryu, T. Kim, K. Kim, J.-H. Ahn, T. Nam, G. Wang and H.-J. Ahn, Journal of Power Sources, 196, 5186 (2011).

26. R. Carter, L. Oakes, A. Douglas, N. Muralidharan, A. P. Cohn and C. L. Pint, Nano letters, 17, 1863 (2017). 
27. M. Pimenta, G. Dresselhaus, M. S. Dresselhaus, L. Cancado, A. Jorio and R. Saito, Physical Chemistry Chemical Physics, 9, 1276 (2007).

28. L. Medenbach, I. Escher, N. Köwitsch, M. Armbrüster, L. Zedler, B. Dietzek and P. Adelhelm, Angewandte Chemie International Edition, 57, 13666 (2018).

29. X. Yu and A. Manthiram, Advanced Energy Materials, 5, 1500350 (2015).

30. Q. Huang and Q. Wang, ChemPlusChem, 80, 312 (2015).

31. D. La Rosa, G. Monforte, C. D'Urso, V. Baglio, V. Antonucci and A. S. Aricò, ChemSusChem, 3, 1390 (2010).

32. X. Lu, J. R. Evans and S. N. Heavens, Journal of the European Ceramic Society, 32, 4219 (2012).

33. O. El Jaroudi, E. Picquenard, N. Gobeltz, A. Demortier and J. Corset, Inorganic Chemistry, 38, 2917 (1999).

34. J. Sangster and A. Pelton, Journal of Phase Equilibria, 18, 89 (1997).

35. K. Ahlbrecht, C. Bucharsky, M. Holzapfel, J. Tübke and M. Hoffmann, Ionics, 23, 1319 (2017).

36. I. Kim, J.-Y. Park, C. Kim, J.-W. Park, J.-P. Ahn, J.-H. Ahn, K.-W. Kim and H.-J. Ahn, Journal of The Electrochemical Society, 163, A611 (2016).

37. T. Wu, Z. Wen, C. Sun, X. Wu, S. Zhang and J. Yang, Journal of Materials Chemistry A, 6, 12623-12629 (2018).

38. C. Yang, G. Nikiforidis, J. Y. Park, J. Choi, Y. Luo, L. Zhang, S. C. Wang, Y. T. Chan, J. Lim and Z. Hou, Advanced Energy Materials, 8, 1702897 (2018). 
(a)

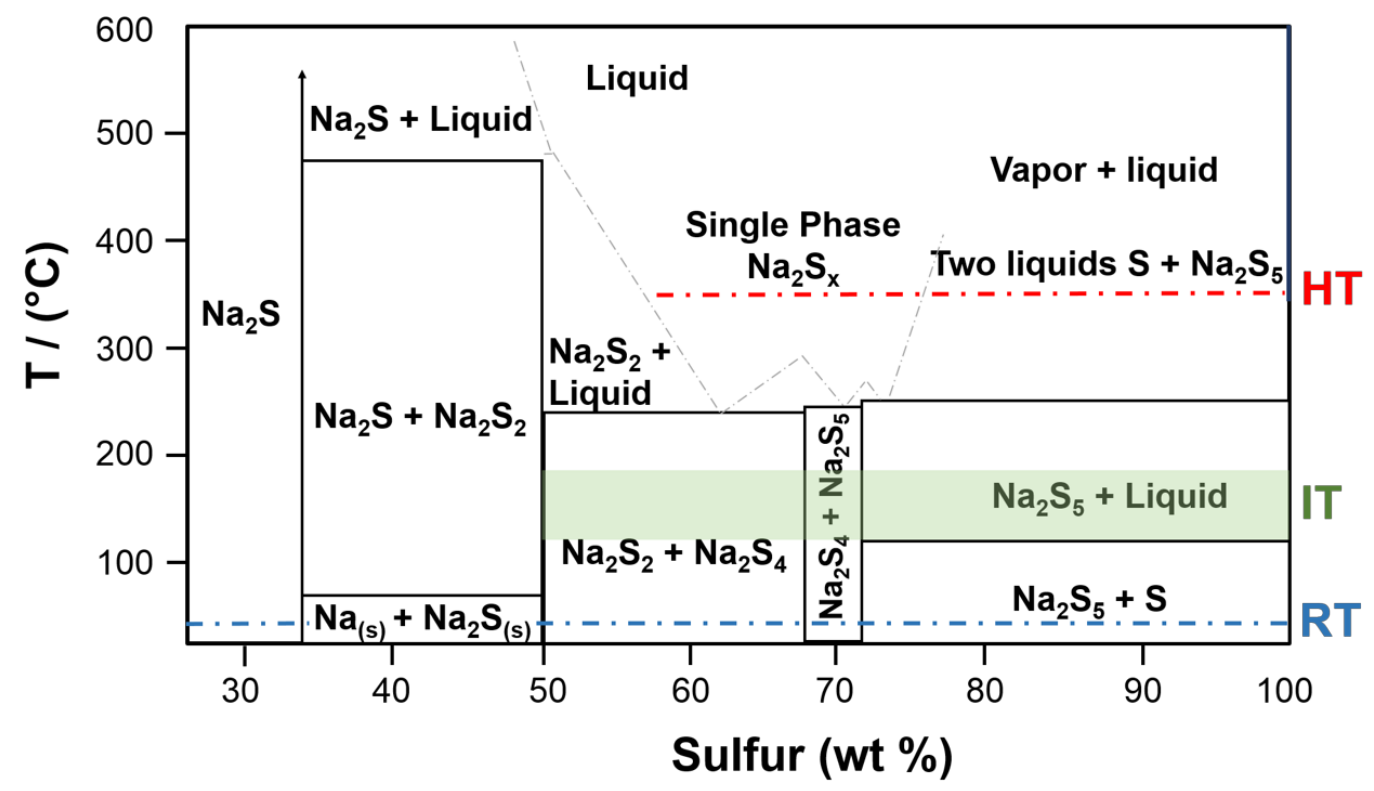

(b)

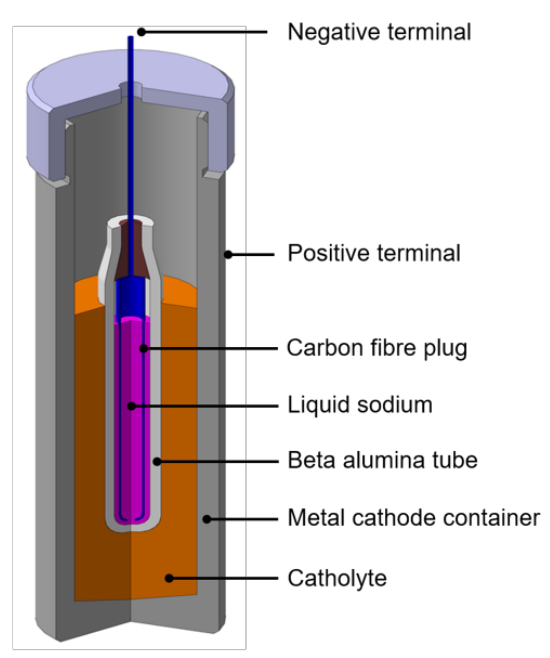

(c)

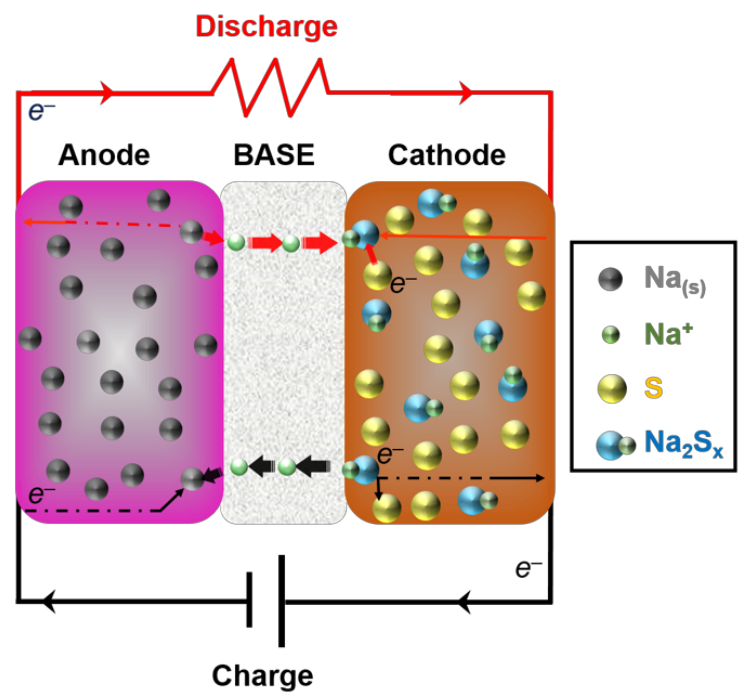

Figure 1. (a) Phase diagram of the NaS system for high, intermediate and room temperatures (HT, IT and RT). Temperature $v s$ weight percentage of sulfur. ${ }^{19}$ (b) Schematic of the tubular IT NaS cell outlining its main components. (c) Diagram depicting the operation of the IT NaS battery. 
(a)

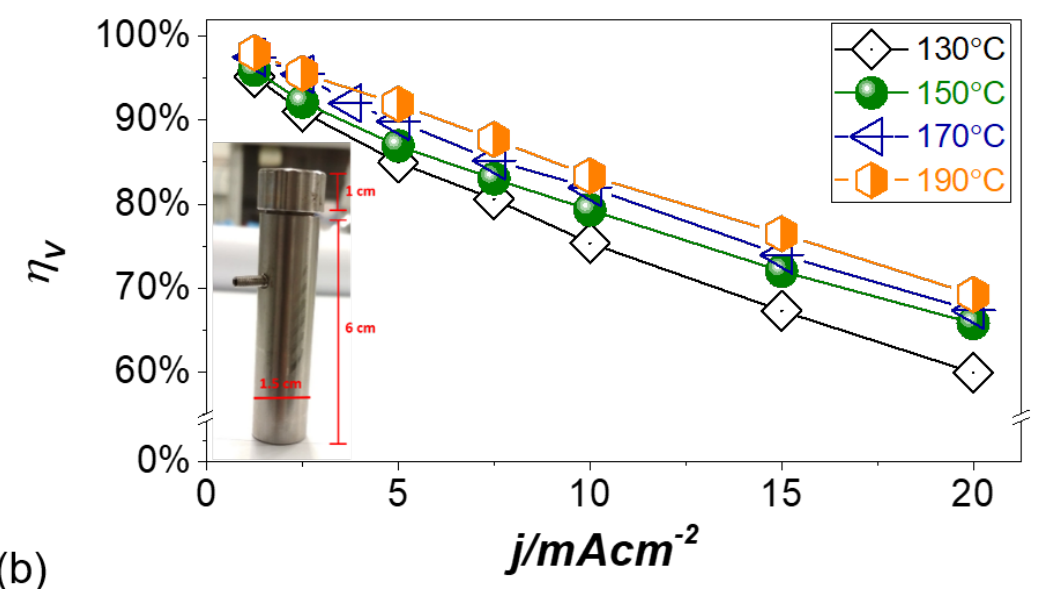

(b)

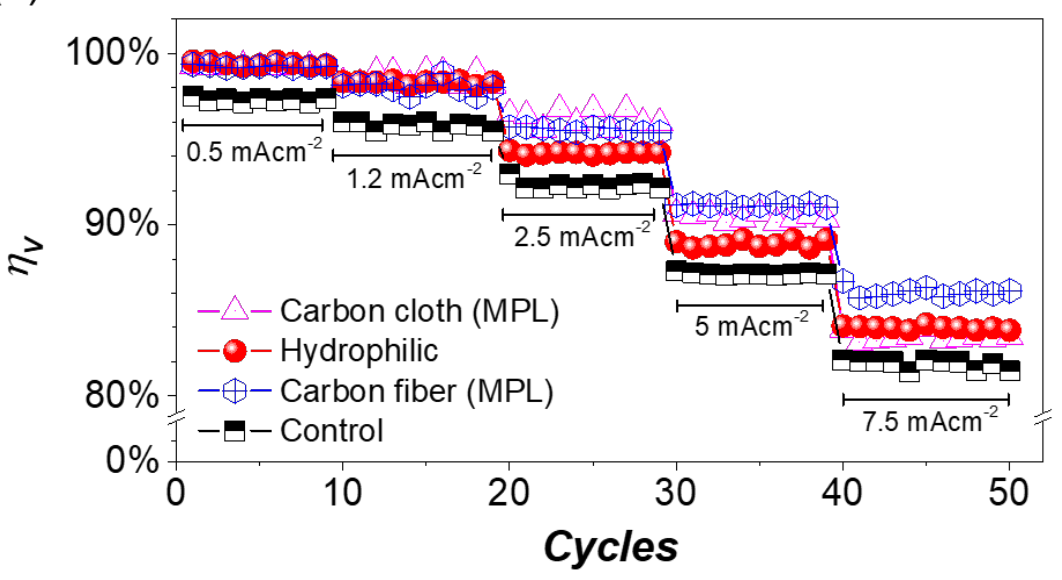

Figure 2. (a) Voltaic efficiency $\left(\eta_{V}\right)$ versus current density $(j)$ at different temperatures on a IT tubular $\mathrm{NaS}$ cell. Catholyte $(4 \mathrm{~mL})$ consists of $2 \mathrm{M} \mathrm{Na}_{2} \mathrm{~S}_{5}$ and TEGDME. Inset shows an optical picture of the micro-stainless steel cell. (b) $\eta_{V}$ as a function of cycles using different carbon cloth materials as current collectors in the cathode at $150^{\circ} \mathrm{C}$. Catholyte is the same as (a). For each current density, 10 cycles were performed with each period lasting $6 \mathrm{~h}$, translating to an overall of 25 days of continuous cycling. 


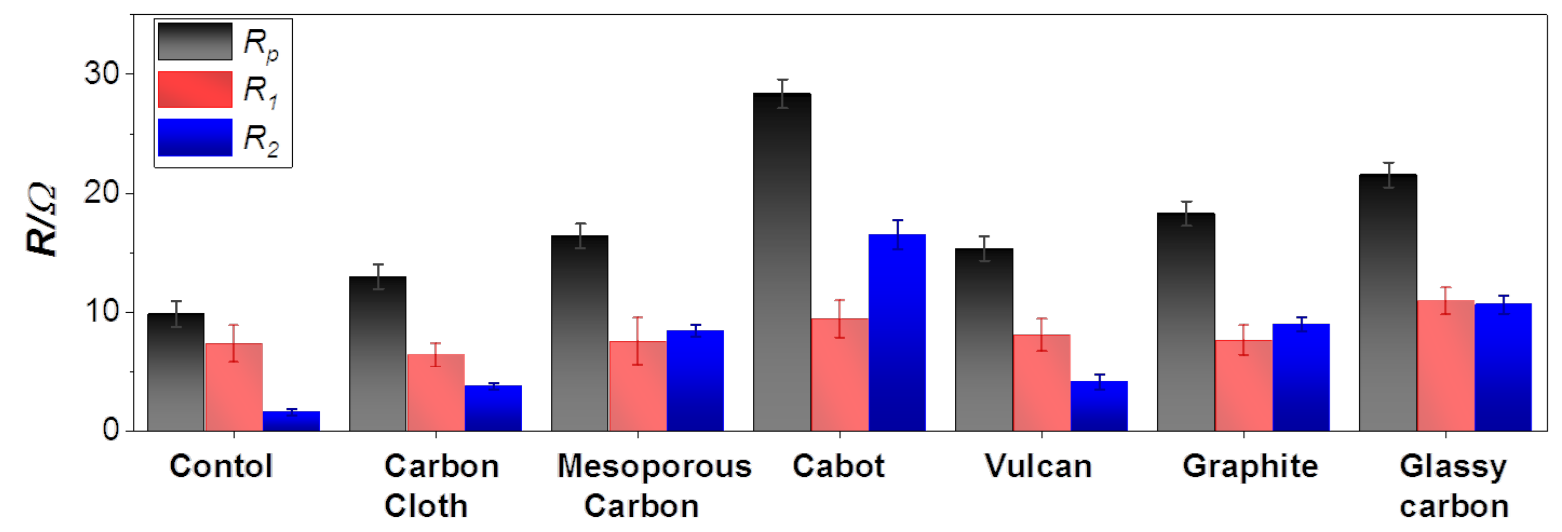

Figure 3. Summary of resistances of the IT NaS tubular cell in a solution consisting of $2 \mathrm{M} \mathrm{Na}_{2} \mathrm{~S}_{5}$ and TEGDME in the presence of different carbon suspensions. The added amount of suspension was $c a$. $1 \mathrm{vol} \%$. For the case of carbon cloth, it was placed perimetrically of the inner stainless steel casing. $R_{p}$ is the cell polarization resistance while $R_{1}$ and $R_{2}$ represent the ohmic and interfacial resistances. Triplicate experiments were performed for each case. 


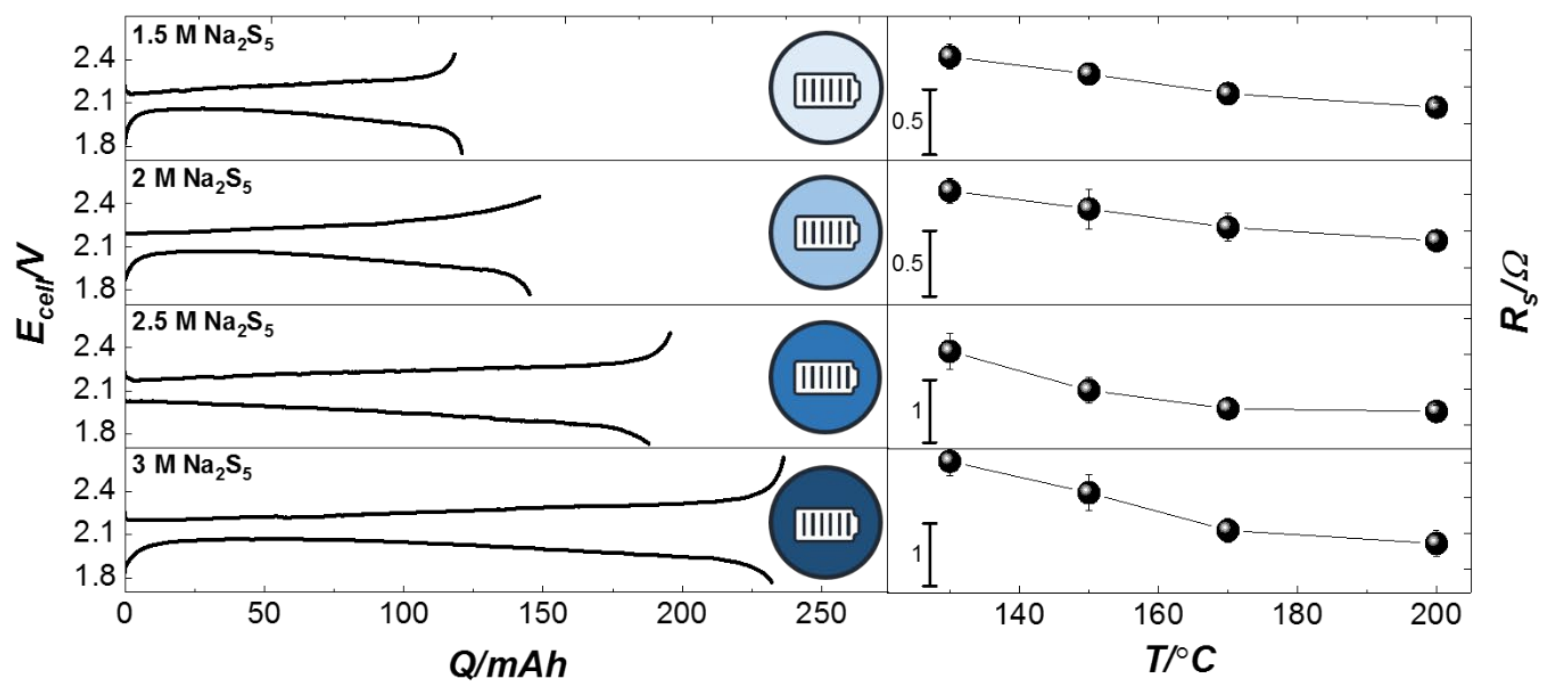

Figure 4. Galvanostatic charge discharge cycles of a tubular IT NaS battery at $\pm 2.5 \mathrm{mAcm}^{-2}$ and different $\mathrm{Na}_{2} \mathrm{~S}_{5}$ concentrations dissolved in TEGDME. Cell operating temperature was $150^{\circ} \mathrm{C}$. Darker colour of the inset denotes the higher concentration of the catholyte. On the right side of the graph, the electrolyte resistance $\left(R_{S}\right)$ of the same catholytes at different temperatures $(130,150$, 170 and $200^{\circ} \mathrm{C}$ ) is displayed. The values of $R_{S}$ stemmed from three-electrode impedance spectroscopy through fitting of a typical Randles circuit. $R_{S}$ was determined at the HF region of the EIS measurement $(0.2 \mathrm{MHz})$ at an amplitude of $10 \mathrm{mV}$. 


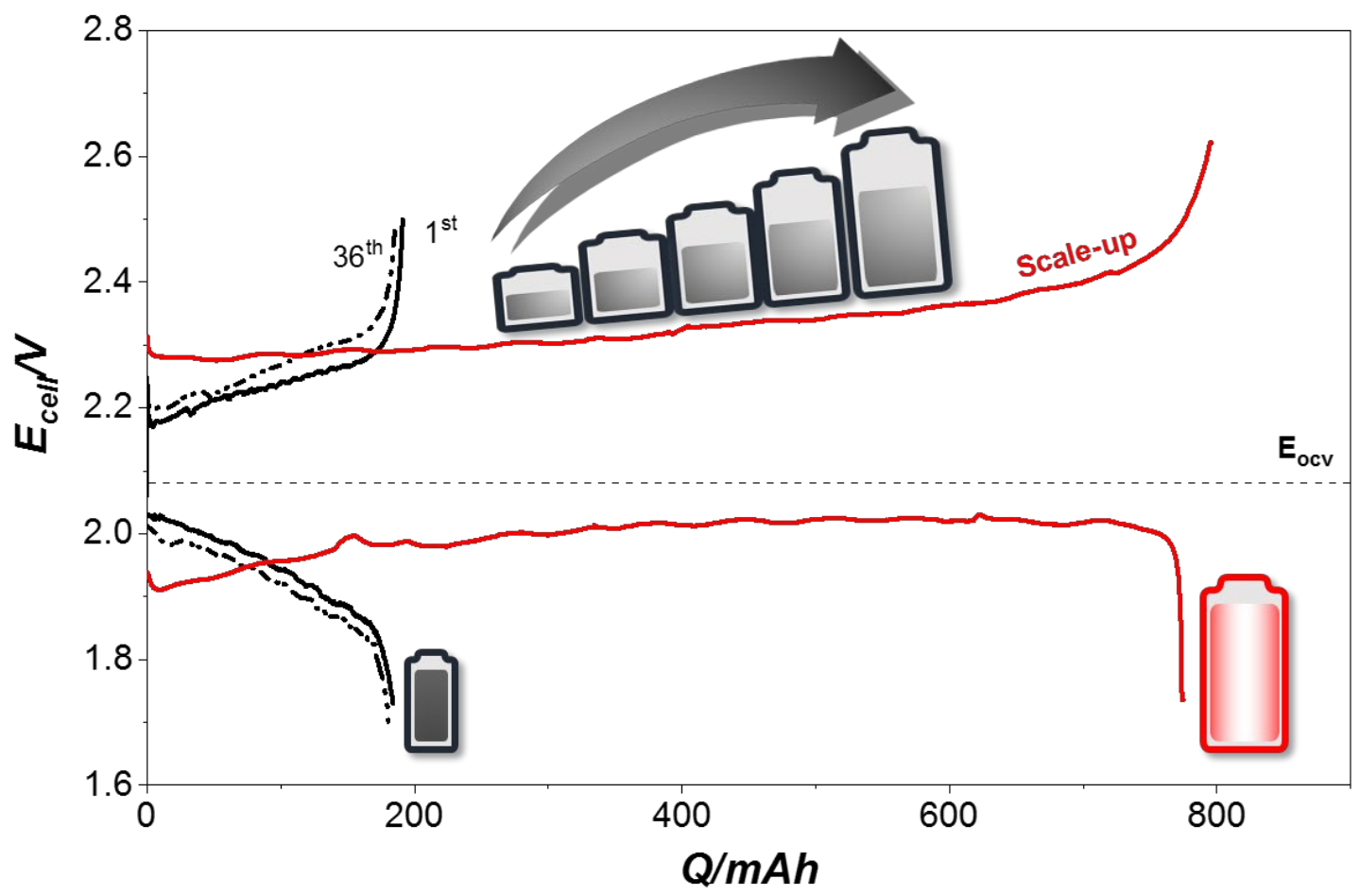

Figure 5. Overlay of capacity retention of a tubular IT NaS battery at $\pm 2.5 \mathrm{mAcm}^{-2}$ in a solution containing $2.5 \mathrm{M} \mathrm{Na}_{2} \mathrm{~S}_{5}$ and TEGDME at $150^{\circ} \mathrm{C}$. Black lines (solid for $1^{\text {st }}$ and doted for $36^{\text {th }}$ cycle) depict the micro-cell and red lines the scale-up. 
(a)

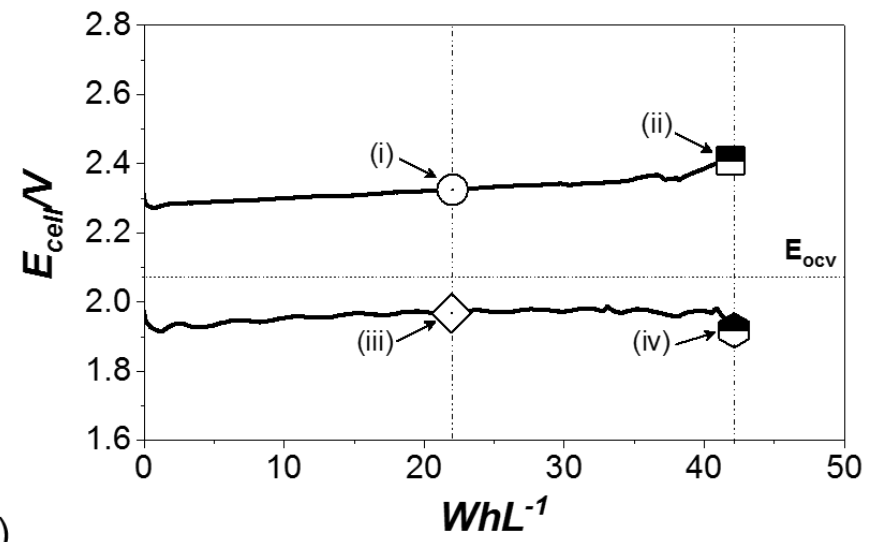

(b)

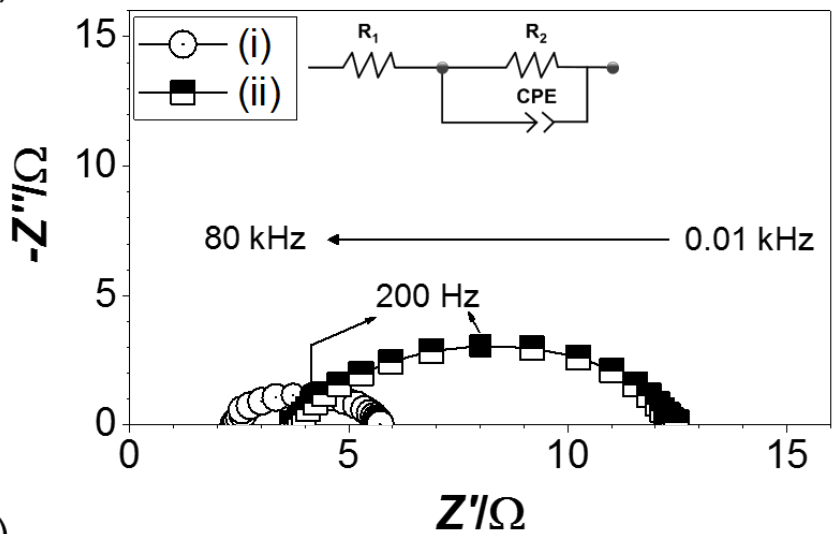

(c)

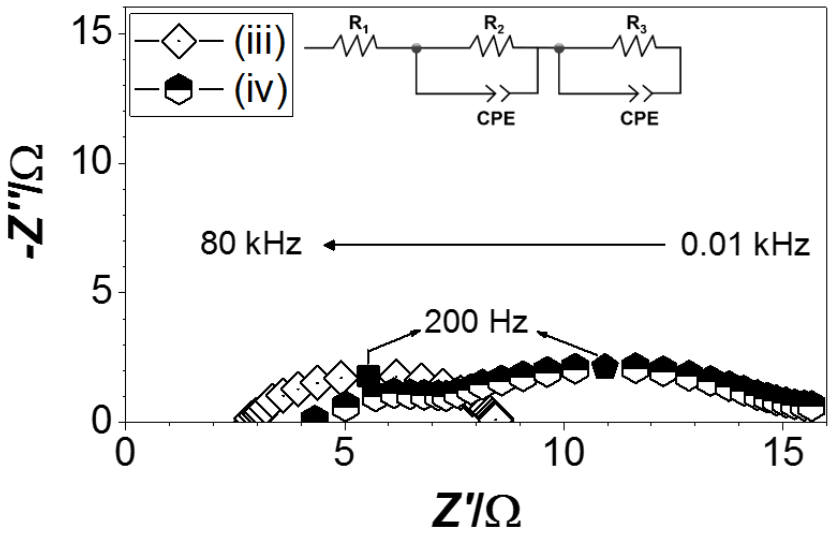

Figure 6. (a) Overlay of a volumetric energy density plot on a tubular IT NaS battery at \pm 2.5 $\mathrm{mAcm}^{-2}$ and in a solution containing $2.5 \mathrm{M} \mathrm{Na}_{2} \mathrm{~S}_{5}$ and TEGDME at $150^{\circ} \mathrm{C}$. (b) (c) Nyquist plots of the cell in relation to the stages marked in (a). Insets show the equivalent circuits used to model the plots. The equivalent circuit for stages (a) (b) and (c) is described by $R_{1}+R_{2} / Q_{2}$ while for (d) is modelled by $\mathrm{R}_{1}+\mathrm{R}_{2} / \mathrm{Q}_{2}+\mathrm{R}_{3} / \mathrm{Q}_{3}$. $E_{\text {ocv }}$ for stages (i) - (iv) was $2.11,2.18,2.09$ and $2.07 \mathrm{~V}$, respectively. 